\title{
PELATIHAN KURIKULUM 2013 PADA GURU-GURU SD GMIM, SD INPRES, SD PANTEKOSTA RAANAN BARU KECAMATAN MOTOLING BARAT KABUPATEN MINAHASA SELATAN
}

\author{
Tommy M. Palapa \\ Prodi Pendidikan Biologi, Fakultas Matematika dan Ilmu Pengetahuan Alam, UNIMA \\ tommypalapa@yahoo.com
}

\begin{abstract}
Abstrak
Peningkatan kualitas pembelajaran matematika semakin gencar dilaksanakan oleh pemerintah. Pemberlakuan kurikulum 2013 yang dicetuskan oleh Kementerian Pendidikan dan Kebudayaan Republik Indonesia sebagai salah satu upaya karena Kurikulum 2013 merupakan kurikulum yang mengutamakan pemahaman, skill dan pendidikan karakter, yaitu siswa dituntut untuk memahami materi pelajaran, aktif dalam berdiskusi dan presentasi serta memiliki sopan santun dan disiplin tinggi. Aspek-aspek yang dikembangkan dari peserta didik diharapkan dapat menghasilkan produk yang tidak hanya hebat dari segi pengetahuan dan terampil menerapkannya, tetapi harus mampu menampakkan sikap yang positif dengan selalu mengakui secara jujur bahwa Tuhan Sang Pencipta adalah sumber segala-galanya dan selalu berusaha menjadi teladan bagi orang lain dalam bertingkah laku. Hal-hal yang dikembangkan ini sangat cocok dengan filosofi 'Memanusiakan manusia (humanizing human being). Tujuan yang ingin dicapai melalui kegiatan pelatihan yaitu (1) untuk mengetahui kemampuan guru tentang penguasaan kurikulum 2013; (2) mengadakan workshop tentang cara menyusun RPP; (3) pemilihan model pembelajaran; dan (4) penyusunan instrument assesmen.
\end{abstract}

Kata Kunci: Kurikulum, RPP, model pembelajaran pembelajaran, assesmen.

\section{PENDAHULUAN}

\section{Analisis Situasi}

Undang-Undang Nomor 20 Tahun

2003 Tentang Sistem Pendidikan Nasional

Pasal 1 butir 19, menjelaskan kurikulum

adalah seperangkat rencana dan pengaturan mengenai tujuan, isi, dan bahan pelajaran serta cara yang digunakan sebagai pedoman penyelenggaraan kegiatan pembelajaran untuk mencapai tujuan pendidikan tertentu. Perkembangan kurikulum di Indonesia sejak jaman kemerdekaan sampai dengan akan diberlakukannya Kurikulum 2013 dapat digambarkan pada diagram dalam Gambar 1.

Dalam implementasi Kurikulum Tingkat Satuan Pendidikan (KTSP) tahun 2006, masih dijumpai beberapa masalah sebagai berikut:
1. Konten kurikulum masih terlalu padat yang ditunjukkan dengan banyaknya matapelajaran dan banyak materi yang keluasan dan tingkat kesukarannya melampaui tingkat perkembangan usia anak.

2. Kurikulum belum sepenuhnya berbasis kompetensi sesuai dengan tuntutan fungsi dan tujuan pendidikan nasional.

3. Kompetensi belum menggambarkan secara holistik domain sikap, keterampilan, dan pengetahuan.

4. Beberapa kompetensi yang dibutuhkan sesuai dengan perkembangan kebutuhan (misalnya pendidikan karakter, metodologi pembelajaran aktif, keseimbangan soft skills dan hard skills, kewirausahaan) belum terakomodasi di dalam kurikulum. 
5. Kurikulum belum peka dan tanggap terhadap perubahan sosial yang terjadi pada tingkat lokal, nasional, maupun global.

6. Standar proses pembelajaran belum menggambarkan urutan pembelajaran yang rinci sehingga membuka peluang penafsiran yang beraneka ragam dan berujung pada pembelajaran yang berpusat pada guru.
7. Standar penilaian belum mengarahkan pada penilaian berbasis kompetensi (proses dan hasil) dan belum secara tegas menuntut adanya remediasi secara berkala.

8. Dengan KTSP memerlukan dokumen kurikulum yang lebih rinci agar tidak menimbulkan multi tafsir.

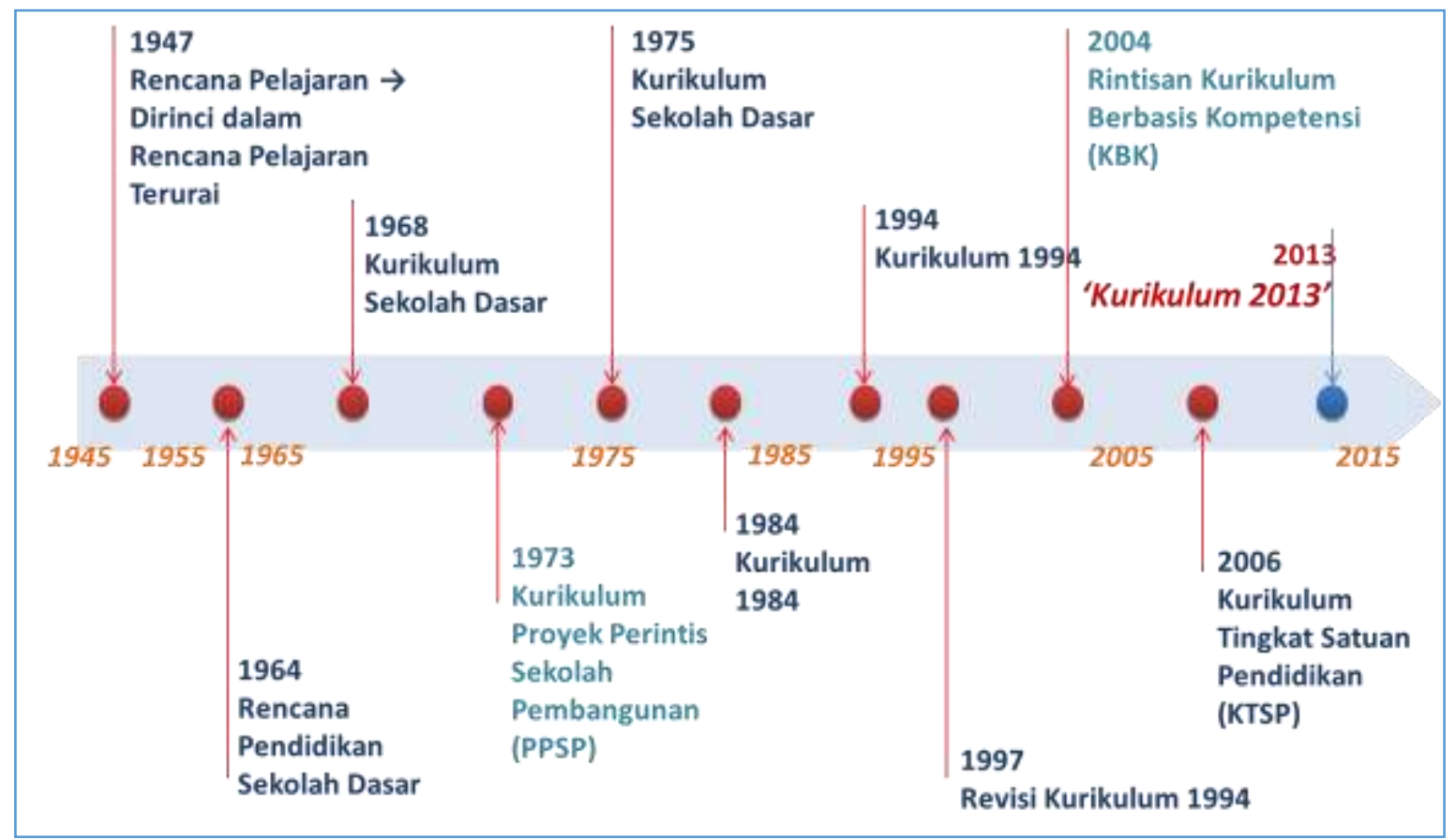

Gambar 1. Perkembangan Kurikulum di Indonesia

Kurikulum $2006 \quad$ (KTSP) dikembangkan menjadi Kurikulum 2013 dengan dilandasi pemikiran tantangan masa depan yaitu tantangan abad ke 21 yang ditandai dengan abad ilmu pengetahuan, knowlwdge-based society dan kompetensi masa depan. Agar pelaksanaan Kurikulum 2013 dapat berjalan dengan baik, perlu dilakukan pelatihan bagi para guru yang akan melaksanakan kurikulum tersebut 154 pada tahun ajaran 2013/2014 yaitu guru SD kelas I, II, IV, V, SMP kelas VII, VIII, dan SMA/SMK kelas X, XI.

Tujuan Pendidikan Nasional (Pasal 3 UU No 20 Sisdiknas Tahun 2003): Berkembang-nya potensi peserta didik agar menjadi manusia yang beriman dan bertakwa kepada Tuhan Yang Maha Esa, berakhlak mulia, sehat, berilmu, cakap, kreatif, mandiri, dan menjadi warga negara 
yang demokratis serta bertanggung jawab; sehingga Menteri Pendidikan dan Kebudayaan memaparkan bahwa perkembangan peserta didik harus ditinjau dan dievaluasi dari tiga aspek, yaitu Sikap (kepada Tuhan dan kepada sesama: Spiritual dan Sosial), Pengetahuan dan Keterampilan, seperti yang digambarkan pada tabel 1.

Tabel 1. Aspek-aspek Perkembangan Peserta Didik

\begin{tabular}{|l|l|}
\hline Sikap Spiritual & Beriman dan bertaqwa kepada Tuhan Yang Maha Esa \\
\hline Sikap Sosial & $\begin{array}{l}\text { Berakhlak mulia, sehat, mandiri, dan demokratis serta bertanggung } \\
\text { jawab }\end{array}$ \\
\hline Pengetahuan & Berilmu \\
\hline Keterampilan & Cakap dan kreatif \\
\hline
\end{tabular}

Aspek-aspek yang dikembangkan dari peserta didik diharapkan dapat menghasilkan produk yang tidak hanya hebat dari segi pengetahuan dan terampil menerapkannya, tetapi harus mampu menampakkan sikap yang positif dengan selalu mengakui secara jujur bahwa Tuhan Sang Pencipta adalah sumber segalagalanya dan selalu berusaha menjadi teladan bagi orang lain dalam bertingkah laku. Hal-hal yang dikembangkan ini sangat cocok dengan filosofi 'Memanusiakan manusia (humanizing human being)'.

$$
\text { Kurikulum dikembangkan atas }
$$
dasar teori pendidikan berdasarkan standar dan teori pendidikan berbasis kompetensi. Pendidikan berdasarkan standar adalah pendidikan yang menetapkan standar nasional sebagai kualitas minimal hasil belajar yang berlaku untuk setiap kurikulum. Standar kualitas nasional dinyatakan sebagai Standar Kompetensi Lulusan. Standar Kompetensi Lulusan tersebut adalah kualitas minimal lulusan suatu jenjang atau satuan pendidikan. Standar Kompetensi Lulusan mencakup sikap, pengetahuan, dan keterampilan (PP nomor 19 tahun 2005). Kurikulum adalah seperangkat rencana dan pengaturan mengenai tujuan, isi, dan bahan pelajaran serta cara yang digunakan sebagai pedoman penyelenggaraan kegiatan pembelajaran untuk mencapai tujuan pendidikan tertentu (UU nomor 20 tahun 2003; PP nomor 19 tahun 2005). Kurikulum dalam dimensi proses adalah realisasi ide dan rancangan kurikulum menjadi suatu proses pembelajaran. Guru adalah tenaga kependidikan utama yang mengembangkan ide dan rancangan tersebut menjadi proses pembelajaran. Pemahaman guru tentang kurikulum akan menentukan rancangan guru (Rencana Program Pembelajaran/ RPP) dan diterjemahkan ke dalam bentuk kegiatan pembelajaran. Peserta didik berhubungan langsung dengan apa yang 
dilakukan guru dalam kegiatan pembelajaran dan menjadi pengalaman langsung peserta didik. Apa yang dialami peserta didik akan menjadi hasil belajar pada dirinya dan menjadi hasil kurikulum. Oleh karena itu proses pembelajaran harus memberikan kesempatan yang luas kepada peserta didik untuk mengembangkan potensi dirinya menjadi hasil belajar yang sama atau lebih tinggi dari yang dinyatakan dalam Standar Kompetensi Lulusan.

Proses pembelajaran pada Kurikulum 2013 untuk semua jenjang dilaksanakan dengan menggunakan pendekatan ilmiah. Proses pembelajaran harus menyentuh tiga ranah, yaitu sikap, pengetahuan, dan keterampilan. Dalam proses pembelajaran berbasis pendekatan ilmiah, ranah sikap menggamit transformasi substansi atau materi ajar agar peserta didik tahu tentang 'mengapa'. Ranah keterampilan menggamit transformasi substansi atau materi ajar agar peserta didik tahu tentang 'bagaimana'. Ranah pengetahuan menggamit transformasi substansi atau materi ajar agar peserta didik tahu tentang 'apa'. Hasil akhirnya adalah peningkatan dan keseimbangan antara kemampuan untuk menjadi manusia yang baik(soft skills) dan manusia yang memiliki kecakapan dan pengetahuan untuk hidup secara layak (hard skills)dari peserta didik yang meliputi aspek kompetensi sikap, keterampilan, dan pengetahuan. Kurikulum 2013 menekankan pada dimensi pedagogik modern dalam pembelajaran, yaitu 156 menggunakan pendekatan ilmiah, pembelajaran berbasis masalah dan menerapkan penilaian autentik.

1. Pendekatan ilmiah (scientific appoach) dalam pembeᄀlajaran semua mata pelajaran meliputi menggali informasi melalui pengamatan, bertanya, percobaan, kemudian mengolah data atau informasi, menyajikan data atau informasi, dilanjutkan dengan menganalisis, menalar, kemudian menyimpulkan, dan mencipta. Untuk mata pelajaran, materi, atau situasi tertentu, sangat mungkin pendekatan ilmiah ini tidak selalu tepat diaplikasikan secara prosedural. Pada kondisi seperti ini, tentu saja proses pembelajaran harus tetap menerapkan nilai-nilai atau sifat-sifat ilmiah dan menghindari nilai-nilai atau sifat-sifat nonilmiah. Pendekatan ilmiah pembelajaran disajikan dalam Gambar 2.

2. Model Pembelajaran mengacu pada:

$\checkmark$ Problem Based Learning. Model pembelajaran berbasis masalah dilakukan dengan adanya pemberian rangsangan berupa masalah-masalah yang kemudian dilakukan pemecahan masalah oleh peserta didik yang diharapkan dapat menambah keterampilan peserta didik dalam pencapaian materi pembelajaran.

$\checkmark \quad$ Project Based Learning. Pembelajar-an Berbasis Proyek (Project Based Learning=PjBL) adalah metoda pembelajaran yang menggunakan proyek/kegiatan 
sebagai media. Peserta didik melakukan eksplorasi, penilaian, interpretasi, sintesis, dan informasi untuk menghasilkan berbagai bentuk hasil belajar.

Pembelajaran Berbasis Proyek merupakan metode belajar yang menggunakan masalah sebagai langkah awal dalam mengumpulkan dan mengintegrasikan pengetahuan baru berdasarkan pengalamannya dalam beraktifitas secara nyata. Pembelajaran Berbasis Proyek dirancang untuk digunakan pada permasalahan komplek yang diperlukan peserta didik dalam melakukan insvestigasi dan memahaminya.

Discovery Learning. Discovery Learning adalah proses belajar yang di dalamnya tidak disajikan suatu konsep dalam bentuk jadi (final), tetapi siswa dituntut untuk mengorganisasi sendiri cara belajarnya dalam menemukan konsep. Sebagaimana pendapat Bruner, bahwa: "Discovery Learning can be defined as the learning that takes place when the student is not presented with subject matter in the final form, but rather is required to organize it him self $\sim$ (Lefancois dalam Emetembun, 1986:103). Dasar ide Bruner ialah pendapat dari Piaget yang menyatakan bahwa anak harus berperan aktif dalam belajar di kelas.

3. Menerapkan Penilaian Autentik, yaitu melakukan penilaian secara menyeluruh menyangkut aspek sikap, pengetahuan dan keterampilan dengan menggunakan instrument tes dan non tes. Penilaian autentik adalah pengukuran yang bermakna secara signifikan atas hasil belajar peserta didik untuk ranah sikap, keterampilan, dan pengetahuan. Istilah penilaian merupakan sinonim dari penilaian, pengukuran, pengujian, atau evaluasi. Istilah autentik merupakan sinonim dari asli, nyata, valid, atau reliabel.

\section{Permasalahan Wilayah}

Permasalahan yang dihadapi para guru Sekolah Dasar (SD) yang ada di Kabupaten Minahasa Selatan Provinsi Sulawesi Utara menyangkut pelaksanaan/ implementasi kurikulum 2013 pada umumnya sama, yaitu sampai pertengahan tahun 2014 belum ada penyamaan persepsi dikarenakan belum semua guru diikutsertakan dalam kegiatan-kegiatan menyangkut implemen-tasi kurikulum 2013, dan belum semua sekolah menjadi sekolah sasaran pelaksanaan/ implementasi kurikulum 2013, padahal pada tahun 2014 kurikulum 2014 sudah diberlakukan di kelas I, kelas II, kelas IV dan kelas V untuk jenjang Sekolah Dasar (SD); kelas VII, kelas VIII untuk jenjang Sekolah Menengah Pertama (SMP) dan kelas X, kelas XI untuk 
jenjang Sekolah Menengah Atas (SMA). Hal ini muncul kerena upaya sosialisasi tentang implementasi kurikulum 2013 harus menjangkau jumlah guru yang banyak dan luas wilayah yang cukup besar, namun dilain pihak waktu yang tersedia untuk pelaksanaan sangat mendesak. Akibat dari situasi ini perlu keterlibatan dari semua komponen yang terkait dengan pelaksanaan kurikulum 2013 termasuk Unima sebagai LPTK yang ada di Sulawesi Utara.

Kecamatan Motoling Barat adalah salah satu kecamatan yang terdapat di Minahasa Selatan yang memiliki sekolah dan guru yang cukup banyak. Berdasarkan data dari semua guru sekolah dasar yang ada baru sekitar $10 \%$ yang memahami implementasi kurikulum 2013 dan siap untuk melaksanakannya pada tahun ajaran baru. Karena itu perlu upaya untuk mensosialisasikan dengan melibatkan sebanyak mungkin guru agar supaya dapat mengimplementasikan dalam kegiatan belajar mengajar pada tahun ajaran baru yang akan dating. Khusus untuk desa Raanan Baru terdapat 3 unit sekolah dasar yang ada yaitu SD GMIM, SD INPRES, dan SD Pantekosta dengan jumlah guru 38 orang dimana bari sekitar 10 orang yang telah mengikuti pelatihan pelaksanaan kurikulum 2013. Bardasarkan uraian di atas, maka masalah dalam kegaiatan ini dapat dirumuskan sebagai berikut :

1. Sejauh mana pemahaman guru sekolah dasar (SD) di desa Raanan Baru tentang pelaksanaan kurikulum 2013
2. Bagaimana pelaksanaan pelatihan kurikulum 2013 pada guru-guru SD di desa Raanan Baru

3. Strategi apa yang dilaksanakan agar guru dapat memahami dan mengimplementasikan kurikulum 2013 dalam pembelajaran di sekolah.

\section{Tujuan Pelaksanaan}

Secara umum tujuan yang ingin dicapat dalam pelaksanaan pelatihan kurikulum 2013 adalah untuk memberikan pemahaman kepada guru-guru tentang implementasi kurikulum 2013. Solusi yang ditawarkan untuk mengatasi masalah penerap-an Kurikulum 2013 di SD GMIM Raanan Baru, SD INPRES Raanan Baru, dan SD Pantekosta Raanan Baru adalah sebagai berikut:

$\checkmark$ sosialisasi tentang implementasi kurikulum kurikulum 2013;

$\checkmark$ mengadakan workshop tentang cara menyusun RPP;

$\checkmark$ mengadakan workshop tentang penerapan model pembelajaran yang diamanatkan kurikulum 2013; dan

$\checkmark$ mengadakan workshop cara menyusun penyusunan instrument assesmen.

\section{Target Luaran}

Luaran yang dihasilkan melalui pengabdian ini ialah peningkatan:

(1) kemampuan guru SD GMIM Raanan Baru, SD INPRES Raanan Baru, dan SD Pantekosta Raanan Baru Sekolah Dasar 
tentang bagaimana menerapkan kurikulum 2013 dalam proses pembelajaran;

(2) keterampilan guru menyusun Rencana Program Pembelajaran (RPP) sesuai kurikulum 2013;

(3) keterampilan dalam memilih dan menerapkan model pembelajaran yang sesuai dengan materi yang akan diajarkan; dan

(4) keterampilan guru menyusun instrument assesmen yang menyangkut sikap, kognitif dan psikomotor.

\section{Kelayakan Pelaksana Pengabdian}

Pelaksana layak melaksanakan Program Pengabdian Masyarakat melalui kegiatan Pelatihan Kurikulum 2013 Pada Guruguru di SD GMIM Raanan Baru, SD INPRES Raanan Baru, dan SD Pantekosta Raanan Baru Kabupaten Minahasa Selatan Provinsi Sulawesi Utara, karena Pelaksana telah membentuk tim sebagai narumber dengan kualifikasi dan pengalaman yang cukup dalam hal penguasaan materi dan teknik sosialisasi dan pelatihan. Tim pelaksana terdiri dari tenaga akademik dari Universitas Negeri Manado dan tenaga fungsional dari Lembaga Penjaminan Mutu Propinsi Sulawesi Utara. Narasumber telah memiliki pengalaman yang cukup karena telah mengikuti pelatihan pada tingkat nasional, bahkan telah menjadi narasumber tingkat nasional. Selain itu pula memeliki pengalaman penelitian bidang pendidikan yang cukup serta kegiatan pengabdian yang dilakakun setiap tahunnya.

\section{METODE PENGABDIAN}

\section{Waktu dan Tempat Pelaksanaan}

Kegiatan pengabdian ini dilaksanakan pada hari kamis - sabtu, tanggal 7 - 9 Agustus 2014 jam 08.00 s/d 16.00 . Bertempat di Sekolah Dasar GMIM Raanan Baru kecamatan Motoling Barat.

\section{Peserta dan Narasumber}

Peserta adalah kepala sekolah dan guru-guru dari 3 sekolah yaitu Sekolah Dasar GMIM Raanan Baru, Sekolah Dasar Inpres Raanan Baru, Sekolah Dasar Pantekosta Raanan Baru dengan jumlah 24 orang (15 orang pe-rempuan dan 11 orang laki-laki), dengan keikutsertaan $100 \%$ penuh. Narasumber terdiri dari dua orang yaitu:

1. Dr. Tommy Martho Palapa, MPd, dosen jurusan Biologi FMIPA UNIMA; dan

2. Dr. Jenny E. Palunsu, MT, Widyaiswara LPMP Sulut.

\section{Tahapan Kegiatan}

Pelaksanaan kegiatan dilaksanakan dalam bentuk tahapan sebagai berikut:

1. Kegiatan awal pelaksanaan kegiatan pengabdian ini adalah ceramah dengan materi kurikulum 2013 dengan nara sumber Dr. Jenny E. Palunsu, MT widyaiswasa dari LPMP Sulut.

2. Kegiatan kedua pelaksanaan kegiatan adalah mendampingi para guru untuk menyusun rencana pelaksanaan pembelajaran berbasis K13. 
3. Evaluasi Kegiatan, dilaksanakan dengan tujuan untuk mengukur sejauh mana tingkat keberhasilan kegiatan berdasarkan tujuan yang ingin dicapai. Adapun hal-hal yang menjadi bahan evaluasi adalah bagaimana peningkatan pengetahuan dan pemahaman para guru tentang kurikulum 2013 dalam kaitan dengan penyusunan rencana pelaksanaan pembelajaran (RPP) dan praktek kegiatan belajar mengajar di sekolah. Mengukur tingkat pengetahuan dan pemahaman guru diukur dengan menggunakan tes yang diikuti oleh seluruh peserta pelatihan, sedangkan untuk mengukur kemampuan menyusun RPP sebagai produk dievaluasi berdasarkan hasil kerja masing-masing guru.

\section{HASIL DAN PEMBAHASAN}

Berdasarkan kegitan yang telah dilaksanakan dalam kegiatan ini, makan diperoleh hasil kegiatan sebagai berikut :

1. Pengetahuan dan pemahaman guru.

Salah satu parameter penilaian untuk mengukur tingkat keberhasilan kegiatan pengabdian masyarakat ini adalah bagaimana pengetahuan dan pemahaman guru tentang kurikulum 2013 (K13) setelah mengikuti kegiatan pelatihan. Peningkatan kemampuan pengetahuan ini diukur dengan melaksanakan tes tertulis dengan jumlah pertanyaan 10 butir dan diikuti oleh seluruh peserta setelah selesai ceramah dilaksanakan. Berdasarkan tes yang telah dilaksanakan menyatakan bahwa $85 \%$ peserta (guru) tergolong kategori menguasai materi K13, sedangkan $15 \%$ tergolong katagori belum menguasai dengan baik sehingga masih perlu penguatan pengetahuan dengan memberikan kesempatan untuk mendalami dalam kegiatan sehari-hari;

2. Kemampuan menyusun RPP. Salah satu tujuan dalam kiegtiatan pengabdian masyarakat ini adalah menupayakan agar supaya guru-guru peserta pelatihan dapat mengimplementasikan pelaksanaan K13 dalam penyusunan rencana pelaksanaan pembelajaran (RPP) sebagai dasar untuk melaksanakan pembelajaran di sekolah. Dalam kaitan dengan hal tersebut, maka strategi pelaksanaan adalah diadakan pendampingan penyusunan. Pendampingan ini dilaksanakan oleh nara sumber selama penyusunan dengan target setiap guru dapat menghasilkan RPP yang lengkap untuk selanjutnya dapat menjadi contoh dan rujukan pribadi atau rekan sekerja guru. Hasil kegiatan pendampingan menunjukkan bahwa semua guru peserta pelatihan dapat menyusun dapat menyusun RPP untuk seklah dasar dengan baik untuk dilaksanakan di sekolah masing-masing. 

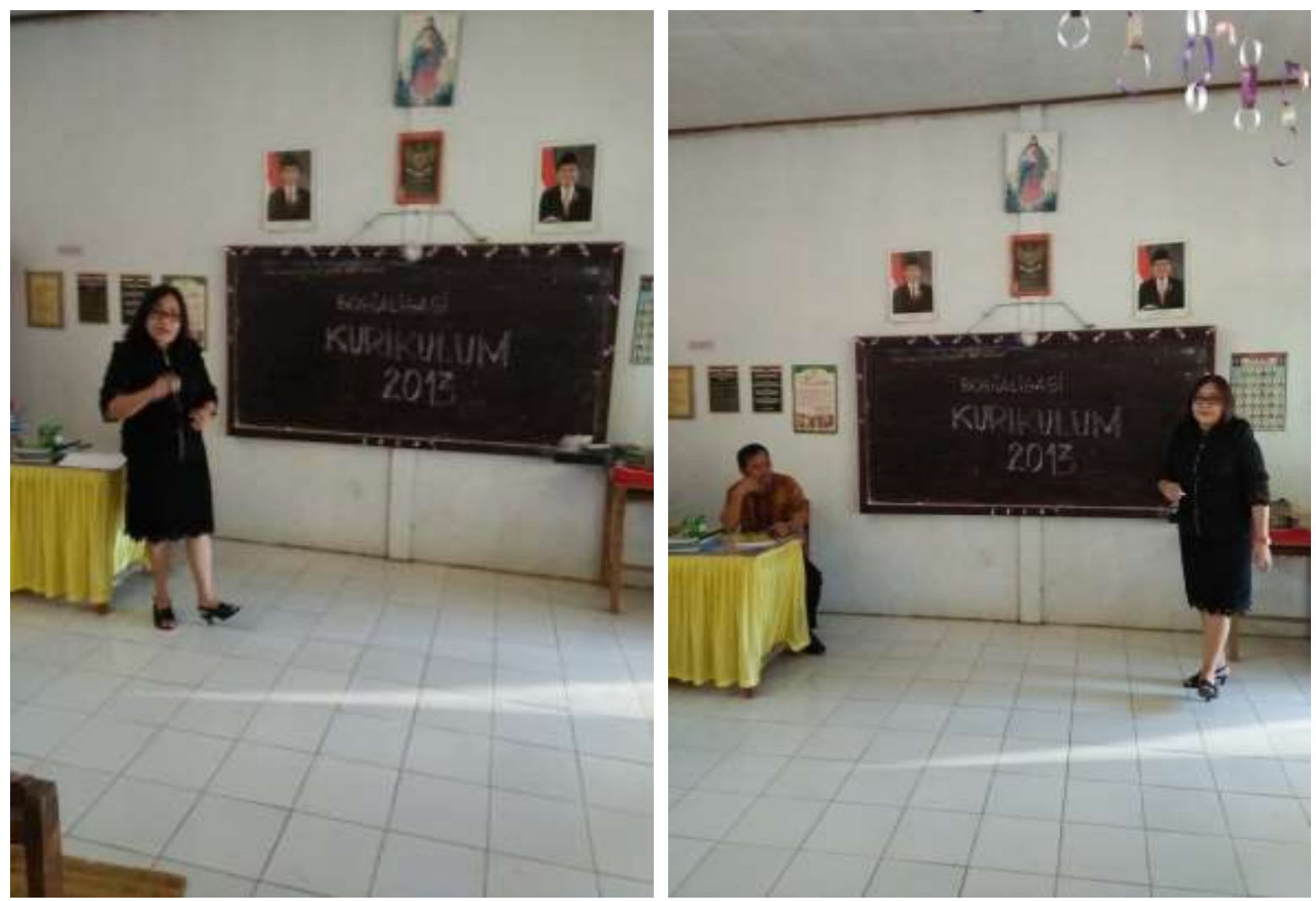

Gambar 2. Dokumentasi Kegiatan: Narasumber sedang Membawakan Materi.

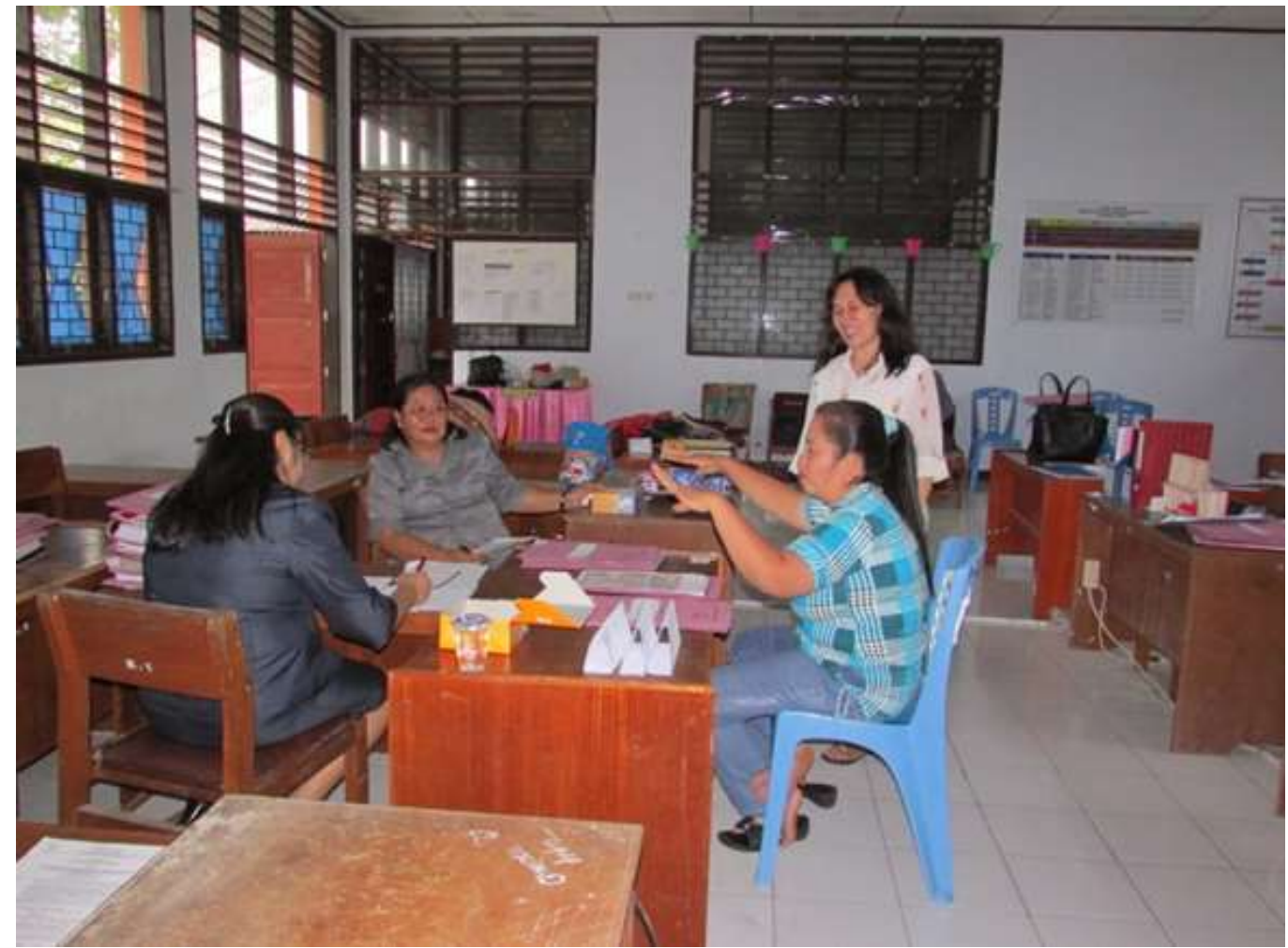

Gambar 3. Dokumentasi Kegiatan: Bimbingan Penyusunan RPP. 


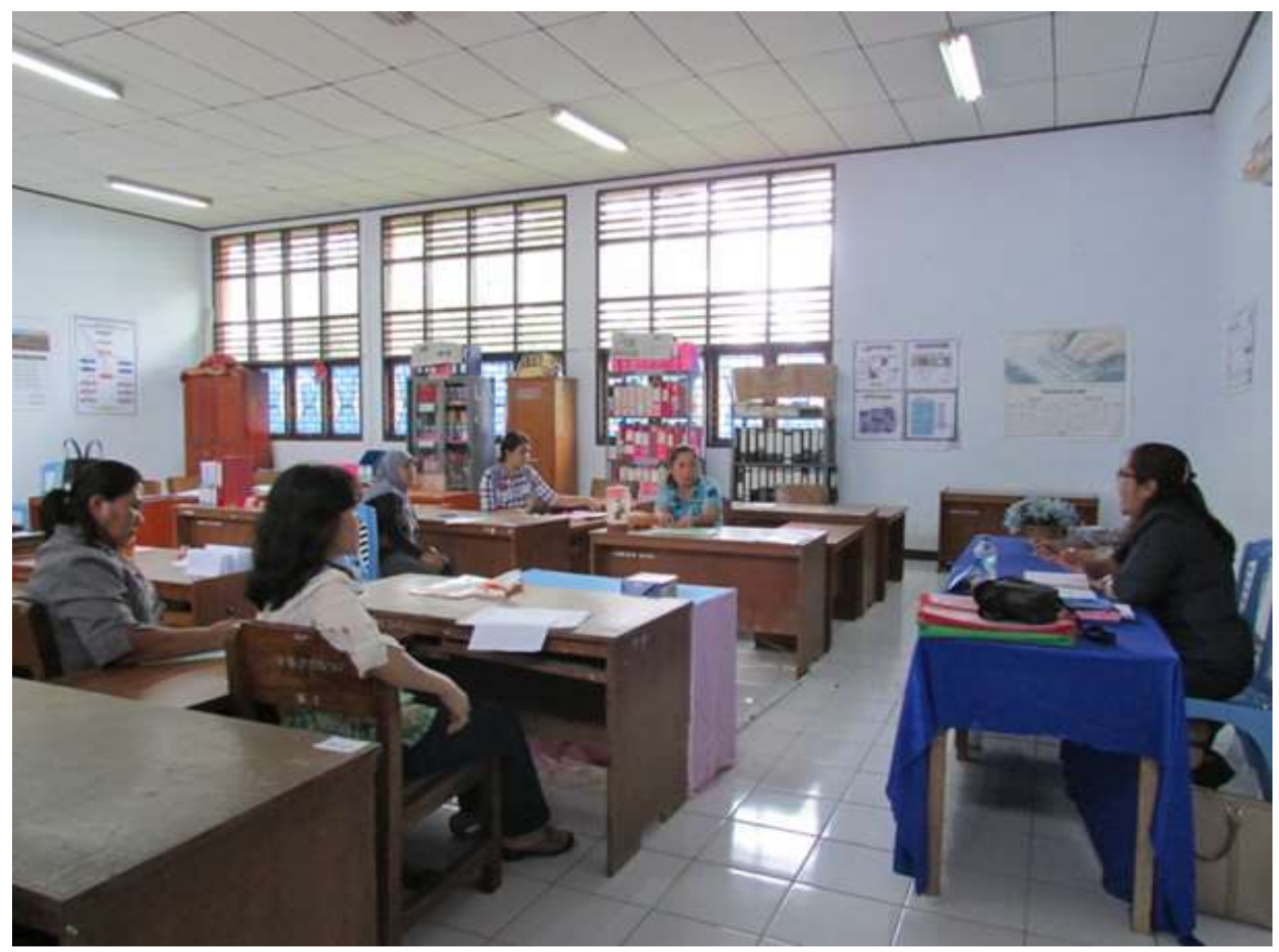

Gambar 4. Dokumentasi Kegiatan: Diskusi Kelompok.

\section{KESIMPULAN DAN SARAN}

\section{Kesimpulan}

Setelah selesai melaksanakan kegiatan dan berdasarkan hasil evaluasi maka pelaksanaan kegiatan pengabdian ini dapat disimpulkan sebagai berikut:

1. Peserta pelatihan sebagian besar (85\%) telah meningkat pemahaman dan pengetahuannya terhadap kurikulum 2013; dan

2. Peserta pelatihan semuanya telah dapat menyusun perangkat pembelajaran dalam bentuk rencana pelaksanaan pembelajaran (RPP).

\section{Saran}

Selanjutnya dapat disarankan sebagai berikut :
1. Pelaksanaan pelatihan dan pendampingan penyusunan RPP dilaksanakan secara rutin tiap awal tahun ajaran; dan

2. Guru mata pelajaran sebaiknya secara rutin memperbaharui dan mengikuti perkembangan kebijakan berkaitan dengan pelaksanaan K13 di sekolah.

\section{KEPUSTAKAAN}

Chambers, Paul. 2007. Teaching Mathematics: Developing as A Reflective Secondary Teacher, Thousand Oaks, CA: Sage Publication Inc.

Danin, S dan Suparno., 2009. Manajemen dan Kepemimpinan Transformasional Kekepalasekolahan. Jakarta:Rineka Cipta.

Dantes, Nyoman. 2008. Hakikat Asesmen Otentik Sebagai Penilaian Proses Dan Produk Dalam Pembelajaran Yang 
Berbasis Kompetensi (Makalah disampaikan pada In House Training (IHT) SMA N 1 Kuta Utara). Singaraja: Universitas Pendidikan Ganesha

Ibrahim, Muslimin. 2005. Asesmen Berkelanjutan: Konsep dasar, Tahapan Pengembangan dan Contoh. Surabaya: UNESA University Press Anggota IKAPI

JoLaine R. Draugalis and Marion K. Slack. 1999. A Continuous Quality Improvement Model for Developing Innovative Instructional Strategies, The University of Arizona.

Kemdikbud. 2013. Pendekatan Scientific (Ilmiah) dalam Pembelajaran . Jakarta: Pusbangprodik.

2013. Paparan Mndikbud
Sosialisasi Kurikulum 2013. Jakarta
:Kemdikbud

Sagala, 2010. Manajemen Strategik DalamPeningkatan Mutu Pendidikan. Bandung: Alfa Beta.

Salusu, 2008. Pengambilan Keputusan Stratejik Untuk Organisasi Publik dan Organisasi Nonprofi. Jakarta: Gramedia Group.

Syah, M., 1996. Psikologi Pendidikan Suatu Pendekatan Baru. Bandung: PT Remaja Rosdakarya.

Syamsudini , 2012. Aplikasi Metode Discovery Learning dalam Meningkatkan Kemampuan Memecahkan Masalah, Motivasi Belajar dan Daya Ingat Siswa.

Undang-undang Sisdiknas, 2003. Undangundang Sistem Pendidikan Nasional. Yogyakarta: Pustaka Pelajar.

Wadsworth, Barry J., 1984. Piaget's Theory of Cognitive and Affective Development (3rd edition). NY: Longman Inc. 
Jurnal ABDIMAS, Vol. 10, No. 01, Juni 2017 ISSN: 1979-0953 